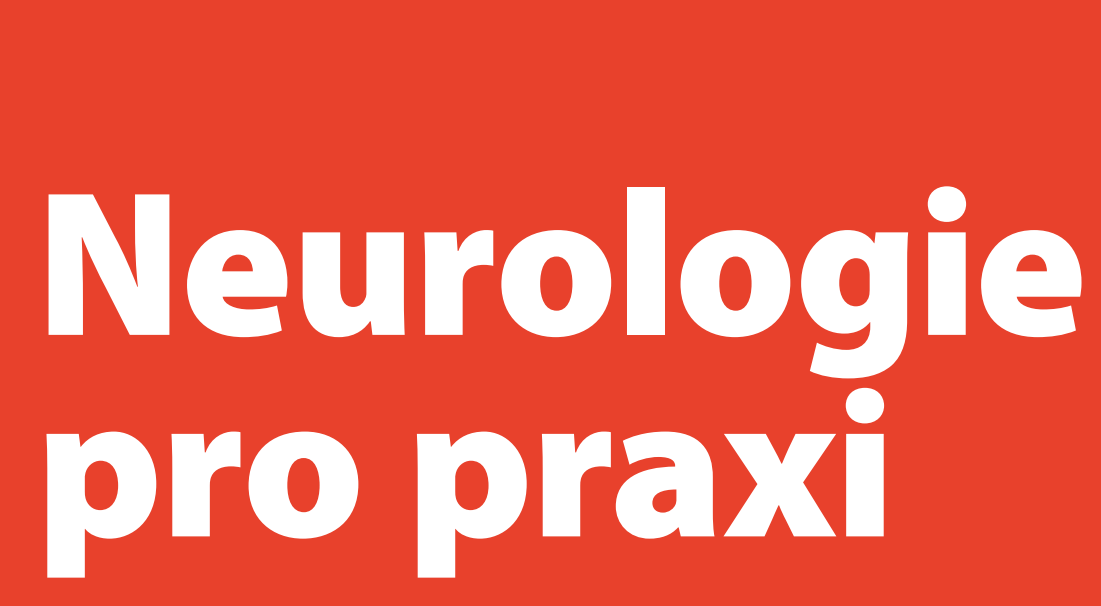

\title{
2020
}

Neurologie

pro prax

www.solen.cz | www.neurologiepropraxi.cz | ISBN 978-80-7471-301-9 | Ročník 21 | 2020

Závažné infekcie komplikujúce

liečbu sclerosis multiplex

doc. MUDr. Eleonóra Klímová, CSc. 



\title{
Závažné infekcie komplikujúce liečbu sclerosis multiplex
}

\author{
doc. MUDr. Eleonóra Klímová, CSc. \\ Klinika neurológie FZO Prešovskej univerzity v Prešove \\ Ambulancia pre sklerózu multiplex FNsP J. A. Reimana, Prešov
}

Za posledné roky sme svedkami obrovského nárastu možností liečby sclerosis multiplex (SM) liekmi s rôznym mechanizmom účinku, ktoré ovplyvňujú imunitný systém imunomoduláciou alebo imunosupresiou. S príchodom nových liekov s vyššou účinnostou, ako poznáme pri interferónoch ß alebo glatiramer acetáte, sa podstatne zmenil manažment liečby pacienta so SM so zretel'om na jeho bezpečnost vrátane predchádzania infekciám, ktoré môžu priebeh SM významne skomplikovat'. Správna indikácia zvoleného lieku novej generácie, ako aj monitoring liečby zvoleným liekom si často vyžaduje širokú multidisciplinárnu spoluprácu. Článok podáva literárny prehlad o výskyte najčastejších infekcií v súvislosti s liečbou týmito liekmi v indikácii SM a možnostiach ich prevencie.

Klúčové slová: sclerosis multiplex, bezpečnost' liečby, infekcie, prevencia.

\section{Serious infections complicating the treatment of multiple sclerosis}

In the recent years, we have witnessed a huge increase in treatment options for multiple sclerosis (MS) with various mechanisms of actions that affect the immune system by immunomodulation or immunosuppression. With the advent of new drugs with higher efficacy than we know in interferons-beta or glatiramer acetate, the management of the patient's treatment with MS with regard to its safety, including the prevention of infections, which can significantly complicate the course of MS. The correct indication of the selected products of the new drugs generation, as well as monitoring of treatment with the chosen medical drug often requires broad multidisciplinary cooperation. The article presents a literary overview of the incidence of most common infections in the treatment with these drugs in the MS indication and how to prevent them.

Key words: multiple sclerosis, safety of treatment, infections, prevention.

\section{Úvod}

Sclerosis multiplex (SM) je chronické zápalové a neurodegeneratívne ochorenie centrálneho nervového systému, invalidizujúce predovšetkým mladých dospelých. $V$ jeho patogenéze zohráva okrem iných faktorov významnú úlohu humorálna a bunkami sprostredkovaná imunita. Za posledné roky sme svedkami obrovského nárastu možností liečby SM liekmi s rôznym mechanizmom účinku, ktoré ovplyvňujú imunitný systém imunomoduláciou alebo imunosupresiou. S príchodom nových liekov (tabul'ka 1) (Buc, 2016) sa podstatne zmenil manažment liečby so zretelom na jej bezpečnost’ vrátane predchádzania infekciám, ktoré môžu priebeh SM aj jej liečbu podstatne skomplikovat'.

V terapii SM aplikujeme interferóny B, glatiramer acetát a iné imunomodulačné a imunosupresívne lieky. Viaceré imunosupresíva si pre svoje potenciálne riziká závažných infekcií vyžadujú pred začatím liečby špeciálne skríningové vyšetrenia a v prípade potreby aj medikamentóznu profylaxiu. Všeobecne, všetci pacienti užívajúci imunomodulanciá a imunosupresíva z akejkolvek indikácie môžu byt v riziku reaktivácie latentných patogénov, zhoršenia asymptomatických chronických a získania nových infekcií. Všetky imunosupresíva (aj tie, ktoré sú indikované na liečbu SM) navodzujú riziká vzniku oportúnnych infekcií (OI) vrátane progresívnej multifokálnej leukoencefalopatie (PML) u pacientov liečených natalizumabom (NTZ). V liečbe SM však boli opísané aj iné nezvyčajné oportúnne infekcie. O interferónoch $ß$ (IFN ß) a glatiramer acetáte (GA) nie je známe, že by spôsobovali oportúnne infekcie. Dôležitým bodom v prevencii infekcií je očkovanie, aj ked' jeho časovanie a kontraindikácie treba dôkladne zvážit' (Epstein et al., 2018). Článok informuje o najčastejších infekciách komplikujúcich liečbu SM.
KORESPONDENČNÍ ADRESA AUTORA: doc. MUDr. Eleonóra Klímová, CSc., eleonora.klimova14@gmail.com Klinika neurológie FZO Prešovskej univerzity v Prešove

Ambulancia pre sklerózu multiplex FNsP J. A. Reimana, Hollého 14, 08181 Prešov
Cit. zkr: Neurol. praxi 2020; 21(Suppl. C): 6-12

Článek prijiat redakcí: 14. 12. 2019

Článek príijat k publikaci: 21. 2. 2020 
Tab. 1. Súhrn mechanizmov pôsobenia, účinnosti a nepriaznivých účinkov nových a perspektívnych liekov v terapii sclerosis multiplex (podla Buca 2016, modifikované)

\begin{tabular}{|c|c|c|c|}
\hline Liek & Mechanizmus účinku & Účinnost' & Nepriaznivé účinky \\
\hline Fingolimod & $\begin{array}{l}\text { Blokuje S1-P receptor, zabraňuje vycestovaniu } \\
\text { T-LY zo sekundárnych lymfoidných orgánov } \\
\text { Možný neuroprotektívny a remyelinizačný } \\
\text { účinok }\end{array}$ & $\begin{array}{l}\text { 54-60 \% ARR-redukcia } \\
\text { Znížené riziko progresie invalidity } \\
\text { Menej nových a zväčšujúcich sa T2-lézií } \\
\text { a spomalenie úbytku objemu mozgu (štúdia } \\
\text { FRREDOM, fáza 3) }\end{array}$ & $\begin{array}{l}\text { Infekcie herpetickými vírusmi, bradykardia, } \\
\text { atrio-ventrikulárny blok, hypertenzia } \\
\text { Zvýšenie hladiny pečeňových enzýmov, } \\
\text { edém makuly, infekcie respiračného traktu, } \\
\text { lymfopénia, možné malignity }\end{array}$ \\
\hline Kladribín & $\begin{array}{l}\text { Analóg adenozínu } \\
\text { Inkorporuje sa do DNA deliacich sa buniek, } \\
\text { prerušujúc tak syntézu DNA a jej opravu } \\
\text { Výsledkom je trvalý a progresívny úbytok aj } \\
\text { CD4+, aj CD8+ T-LY }\end{array}$ & $\begin{array}{l}\text { 55-58 \% ARR-redukcia } \\
86-88 \% \text { redukcia Gd+' lézií, redukované riziko } \\
\text { vývoja invalidity (štúdia CLARITY, fáza 3) }\end{array}$ & $\begin{array}{l}\text { Lymfopénia, neutropénia, trombocytopénia, } \\
\text { pancytopénia, reaktivácia herpes zoster, } \\
\text { možné malignity }\end{array}$ \\
\hline Teriflunomid & $\begin{array}{l}\text { Aktívny metabolit leflunomidu } \\
\text { Inhibuje mitochondriovú dihydroorotát- } \\
\text { dehydrogenázu } \\
\text { Zabraňuje de novo syntéze pyrimidínov, } \\
\text { inhibuje proliferáciu a efektorové funkcie } \\
\text { aktivovaných B a T-LY }\end{array}$ & $\begin{array}{l}\text { Spomalenie vyvíjajúcej sa invalidity, } 61 \% \\
\text { redukcia Gd+ lézií } \\
31 \text { \% ARR-redukcia } \\
\text { Spomalenie progresie choroby (štúdia } \\
\text { TEMSO, fáza 3) }\end{array}$ & $\begin{array}{l}\text { Hnačky, nauzea, zvýšené hladiny pečeňových } \\
\text { enzýmov, alopécia, kožné vyrážky, infekcie, } \\
\text { neutropénia, hypertenzia }\end{array}$ \\
\hline Dimetylfumarát & $\begin{array}{l}\text { Antioxidačný a imunomodulačný účinok } \\
\text { Môže pôsobit' neuroprotektívne }\end{array}$ & $\begin{array}{l}53 \% \text { ARR-redukcia } \\
85 \% \text { redukcia nových, resp. zväčšujúcich sa } \\
\text { T2-lézií } \\
90 \text { \% redukcia Gd+ lézií } \\
38 \text { \% redukcia progresie invalidity (štúdia } \\
\text { DEFINE, fáza 3) }\end{array}$ & $\begin{array}{l}\text { Začervenanie, bolesti hlavy, brucha, } \\
\text { nauzea, vracanie, hnačky zvýšenie hladiny } \\
\text { pečeňových enzýmov ( } \text { závislosti od dávky) }\end{array}$ \\
\hline Alemtuzumab & $\begin{array}{l}\text { Humanizovaná mAb anti-CD52 } \\
\text { Spôsobuje komplementom alebo K-bunkami } \\
\text { mediovanú lýzu CD4+, CD8 }{ }^{+} \text {T-LY a B-LY, NK } \\
\text { buniek a monocytov } \\
\text { Pretrvávanie znížených počtov B-LY je kratšie } \\
\text { ako T-LY }\end{array}$ & $\begin{array}{l}74 \text { \% redukcia RR, } 71 \text { \% zníženie rizika vývoja } \\
\text { trvalej invalidity } \\
\text { Signifikantné zníženie straty objemu mozgu } \\
\text { (štúdia CAMMS223, 2. fáza) }\end{array}$ & $\begin{array}{l}\text { Postinfúzne problémy, autoimunitné choroby } \\
\text { ŠTŽ, autoimunitná trombocytopénia, } \\
\text { neutropénia, hemolytická anémia } \\
\text { Goodpasturov syndróm, infekcie } \\
\text { respiračného traktu, rekurentný orálny } \\
\text { herpes, možno meningitídy a malignity }\end{array}$ \\
\hline Rituximab & $\begin{array}{l}\text { Chimérová mAb anti-CD20 } \\
\text { Spôsobuje depléciu B-LY a potláča ich } \\
\text { prozápalové funkcie (kpoklesu hladín lgG } \\
\text { nedochádza ani v plazme, ani v CSL) }\end{array}$ & $\begin{array}{l}91 \text { \% redukcia počtu Gd+ lézií, zníženie počtu } \\
\text { relapsov ( } 2 \text {. fáza klinických skúšok) }\end{array}$ & $\begin{array}{l}\text { Postinfúzne reakcie, infekcie urogenitálneho } \\
\text { traktu, sinusitídy, PML }\end{array}$ \\
\hline Ocrelizumab & $\begin{array}{l}\text { Humanizovaná mAb, anti-CD20 } \\
\text { Účinkuje podobne ako rituximab }\end{array}$ & $\begin{array}{l}\text { 73-80 \% ARR redukcia } \\
\text { 89-96 \% zníženie Gd+ lézií }\end{array}$ & $\begin{array}{l}\text { Postinfúzne reakcie (najmä po prvom } \\
\text { podaní), oportunistické infekcie (u SLE } \\
\text { a RA-pacientov po predchádzajúcej liečbe } \\
\text { metotrexátom) }\end{array}$ \\
\hline Ofatumumab & $\begin{array}{l}\text { Humánna mAb anti-CD20 } \\
\text { Účinkuje podobne ako rituximab }\end{array}$ & $\begin{array}{l}\text { 99,8 \% redukcia počtu nových } \mathrm{Gd}^{+} \text {lézií a aj } \\
\text { podobné zníženie nových či zväčšujúcich sa } \\
\text { T2 lézií }\end{array}$ & Nedostatočné údaje \\
\hline Siponimod & $\begin{array}{l}\text { Modulátor sfingozín-1P receptora, blokuje } \\
\text { uvolinovanie LY z lymfatických uzlín, } \\
\text { redukujúc tak počet LY v periférnej krvi a ich } \\
\text { migráciu do CNS } \\
\text { Štúdia EXPAND/pri SPSM }\end{array}$ & $\begin{array}{l}30 \text { \% redukcia rizika potvrdenej progresie } \\
\text { disability do } 3 \text { mesiacov, do } 6 \text { mesiacov } 26 \% \\
89 \% \text { verzus } 67 \% \text { (placebo) pacientov bez } \\
\text { Gd+ lézií a bez nových alebo zväčšených T2 } \\
\text { lézií } 57 \text { verzus } 37 \% \\
\text { Žiaden efekt na T25FW }\end{array}$ & Žiaden efekt na T25FW \\
\hline
\end{tabular}

\section{Tuberkulóza}

Aktívna tuberkulóza (TBC) vzniká u dospelých reaktiváciou latentných bakteriálnych ložísk, ktoré boli dovtedy pod imunologickou kontrolou. Potenciálnej reaktivácii alebo progresii TBC sú vystavení predovšetkým pacienti liečení liekmi ovplyvňujúcimi bunkami sprostredkovanú imunitu. Bez ohladu na imunosupresívnu medikáciu a výsledky testov na TBC je liečba latentnej TBC infekcie (LTBI) odporúčaná u pacientov v krajinách s vysokým výskytom TBC, migrantov z týchto krajín, pacientov s diabetes mellitus alebo chronickým obličkovým zlyhávaním. V súčasnosti existujú 4 liečebné schémy na liečbu LTBI s aplikáciou rifampínu a izoniazidu v rôznych 
dávkovacích režimoch, o indikácii ktorých rozhoduje špecialista (Center for Disease Control and Prevention, 2017). Z testov na odhalenie LTBI sa využívajú predovšetkým krvné testy, tzv. IGRA-testy (Interferon Gamma Release Assay), ku ktorým patria T-SPOT a Quantiferónový test.

Alemtuzumab (ALZ), anti-CD52 monoklonová protilátka, navodenou prolongovanou hlbokou lymfocytopéniou ovplyvňuje obe, humorálnu aj bunkami sprostredkovanú imunitu. V obidvoch pilotných štúdiách III. fázy s liekom (CARE-MS I a CARE-MS II) sa však TBC vyskytla iba u 2 z > 900 liečených pacientov alemtuzumabom. Prípady TBC sa vyskytli napriek odporúčanému rozšírenému skríningu na LTBI v týchto štúdiách, v CARE-MS II boli dokonca aj pacienti so SM z endemických oblastí výskytu TBC. ALZ sa spája s vysokým výskytom TBC u pacientov s hematologickými zhubnými ochoreniami, ktorí sú však už od "základu“ pri charaktere svojho ochorenia vo zvýšenom riziku tejto infekcie (Epstein et al., 2018). Pre všetky tieto dôvody je skríning na LTBI indikovaný pred liečbou ALZ pri SM.

Teriflunomid (TRF), inhibítor dihydroorotát dehydrogenázy, narušuje syntézu pyrimidínov, čím ovplyvňuje proliferáciu lymfocytov a môže tak potenciálne ovplyvnit’ riziko reaktivácie TBC. Doteraz boli celkovo zachytené 4 prípady tuberkulózy u viac než 2000 pacientov liečených TRF (Comi et al., 2016; Vermersch et al., 2014; Sanofi Genzyme data on file, 2019). Európske SPC lieku neuvádza potrebu skríningového vyšetrenia na LTBI pred iniciáciou liečby. Bezpečnost' TRF u pacientov s LTBI nie je známa, ked'že sa skríningové vyšetrenia na TBC v klinických štúdiách nevykonávali systematicky. U pacientov s pozitívnymi výsledkami skríningového vyšetrenia na LTBI je potrebné infekciu liečit’ štandardným liečebným postupom pred začiatkom liečby teriflunomidom (SPC lieku Aubagio [online]. www.sukl.sk).

Kladribín, analóg adenozínu, môže znížit obranyschopnost' imunitného systému organizmu a zvýšit pravdepodobnost výskytu infekcií. Môže dôjst’ k aktivácii latentných infekcií vrátane TBC alebo hepatitídy B a C, preto sa pred začatím liečby v 1. a 2. roku odporúča realizovat’ skríning na predmetné latentné infekcie. Začatie liečby kladribínom sa má odložit, až kým sa infekcia riadne nevylieči (SPC lieku Mavenclad [online]. www.sukl.sk).
Pri ocrelizumabe (OCR), anti-CD20 monoklonovej protilátke, sa pri mechanizme jeho účinku, ktorého výsledkom je deplécia B-lymfocytov (B-LY) s minimálnym zásahom do bunkami sprostredkovanej imunity, nepredpokladá signifikantné zvýšenie rizika reaktivácie TBC. Tri velké klinické štúdie s ocrelizumabom nevyžadovali skríning na LTBI a ani v ich výsledkových správach sa prípad TBC nevyskytol.

Podobne aj d’alšia monoklonová protilátka cielená na CD20 - rituximumab, je spojená s pozoruhodne nízkym rizikom reaktivácie TBC u pacientov liečených týmto liekom pre reumatologické ochorenia. Skríning na LTBI pred indikáciou anti-CD20 monoklonových protilátok sa povinne nevyžaduje.

Riziko reaktivácie TBC pre pacientov liečených natalizumabom, fingolimodom alebo dimetylfumarátom je pravdepodobne hraničné - pohybuje sa v intenciách rizika chorých liečených anti-CD20 monoklonovými protilátkami, alemtuzumabom alebo teriflunomidom. Pre tieto tri lieky by sa mal zvážit skríning LTBI u pacientov vo vysokom epidemiologickom riziku pre infekciu alebo s inými rizikovými faktormi reaktivácie TBC. Sporadické sú údaje o riziku reaktivácie TBC u pacientov liečených mitoxantrónom. Avšak imunosupresívne vlastnosti lieku a chýbanie spolahlivých bezpečnostných údajov ohladom reaktivácie infekcií sú dôvodom na zváženie skríningu LTBI aj u týchto chorých (Epstein et al., 2018).

\section{Infekcia vírusom hepatitídy B (HBV)}

Sérologické testy na zistenie infekcie HBV sú vysoko senzitívne a špecifické, farmakoterapia HBV je pomerne nenáročná - takže obidva tieto fakty majú dosah na analýzu rizika verzus benefitu týkajúcich sa skríningu, liečby a profylaxie ochorenia. Najlepšou liečebnou stratégiou pre pacientov vo vysokom riziku reaktivácie HBV je profylaxia protivírusovými liekmi, ktoré sú efektívne a bezpečné. Alternatívou k profylaktickej liečbe je preventívne monitorovanie HBVDNA pomocou PCR (Polymerase Chain Reaction) každé 3 mesiace, s následnou iniciáciou protivírusovej terapie, ak je potrebná (Reddy et al., 2015).

Oboje - profylaxia aj preventívny prístup sa u rizikových pacientov typicky odporúča počas imunosupresie a 6 mesiacov po jej ukončení okrem pacientov liečených anti-CD20 monoklonovými protilátkami, ktorí sú v riziku infekcie HBV až do 12. mesiacov po poslednej dávke lieku. Anti-CD20 monoklonové protilátky, ktorou je v liečbe SM aktuálne ocrelizumab, predstavujú vysoké riziko pre asociovanú HBV a poškodenie pečene. Preto by mal každý pacient liečený ocrelizumabom so sérologickou pozitivitou HBV infekcie $v$ minulosti alebo $v$ súčasnosti dostat profylaktickú antivírusovú terapiu počas a 12 mesiacov po ukončení imunosupresie (Reddy et al., 2015). Obdobné riziko vzniku HBV infekcií predstavuje aj kladribín, pri ktorom sa musí pred začatím liečby v 1. a 2. roku realizovat' skríning na hepatitídu B a C.

Riziká aktivácie HBV infekcie u pacientov liečených fingolimodom, dimetylfumarátom a teriflunomidom neboli pevne stanovené, ale sú pravdepodobne nízke. Vo výsledkoch nosných klinických skúšok uvedených liekov neboli hlásené závažné ochorenia pečene. Pre pacientov liečených ntrónom je riziko aktivácie HBV infekcie neznáme, avšak chemicky príbuzné a častejšie používané lieky antracyklínovej triedy sú spojené s relatívne vysokým rizikom aktivácie tejto infekcie.

Žiadne prípady hepatitídy B neboli hlásené vo vel'kých klinických skúškach s natalizumabom, aj ked'sa zdá, že integríny môžu napadnút transport lymfocytov v pečeni, implikácia kontroly HBV infekcie $v$ manažmente liečby NTZ je nejasná.

Vzhladom na známe alebo potenciálne riziko aktivácie HBV by mali mat̉ všetci pacienti so SM pred plánovanou liečbou imunosupresívnymi liekmi vyšetrený HBsAg a anti-HB antigén (Epstein, 2018).

\section{Progresívna multifokálna leukoencefalopatia (PML)}

JC vírus (JCV), etiologické agens PML, je ubikvitárny, dvojito špirálový DNA vírus so séroprevalenciou viac ako 50 \% vo väčšine študovanej populácie. Mechanizmus jeho transmisie je neznámy, najvyššia prevalencia vírusu je v urogenitálnych tkanivách. Bunkami sprostredkovaná imunita chráni imunokompetentných jedincov pred klinicky signifikantnou reaktiváciou infekcie JCV, ale nedostatočná imunologická kontrola umožňuje infikovat’ oligodendrocyty a astrocyty, ktorej výsledkom je demyelinizácia, najčastejšie subkortikálnej bielej hmoty alebo v bielej hmote 
mozočkových hemisfér a pedunkulov v klinickej podobe PML. PML je obávanou oportúnnou infekciou predovšetkým u pacientov liečených natalizumabom (Brew at al., 2010).

$\checkmark$ rámci stratifikácie rizika PML boli stanovené tri triedy liekov (Berger, 2017).

\section{Lieky I. triedy}

Do tejto triedy liekov patrí len natalizumab. Do 28. februára 2018 dostalo NTZ približne 181300 pacientov s celkovým počtom 638 838 pacient-rokov expozície na celom svete po uvedení lieku na trh. K identickému dátumu bol celkový výskyt PML u pacientov liečených NTZ 4,16/1 000 pacientov (95\% Cl 3,87 až 4,46 na 1000 pacientov). K 1. marcu 2018 bolo potvrdených 766 prípadov PML (763 SM, 3 Crohnova choroba), (208 USA, 484 EEA - European Economic Area, 74 ROW - Rest of World). K 1. marcu 2018 sa dĺžka podávania NTZ pred diagnózou PML pohybovala od 8 do 44 dávok, priemerná dľžka podávania NTZ v čase diagnózy PML bola približne 50 infúzií (Biogen SR, 2018).

Za rizikové faktory pre PML asociovanú s natalizumabom PML/NTZ sú považované predchádzajúca imunosupresia, prolongované trvanie liečby NTZ (spravidla > ako 24 mesiacov) a prítomnost' protilátok proti JC vírusu (anti-JCV protilátky), ktoré sú $>98 \%$ senzitívne v predikcii rozvoja PML, ale vel'mi nešpecifické.

Sérokonverzia s rozvojom de novo detegovaných anti-JCV protilátok sa každoročne vyskytuje do $10 \%$ pacientov liečených NTZ, ale nezdá sa, že by predstavovala d’alšie riziko PML nad rámec, ktorý súvisí so séropozitívnym stavom. Význam séroreverzie, ktorá sa tiež vyskytuje, zostáva nejasný. Vo všeobecnosti sa predpokladá, že takíto pacienti majú riziko PML podobné ako chorís pretrvávajúcou séropozitivitou protilátok. $\checkmark$ poslednom období nadobudol význam anti-JCV index, odzrkadlujúci titer protilátok normalizovaný k štandardizovaným sérovým kontrolám a ukázal sa byt viac prediktívny pre rozvoj PML ako kvantitatívna hladina protilátok (Schwab et al., 2017; Ho et al., 2017).

Protilátky proti JC vírusu sa štandardne testujú pred začatím liečby, 12 mesiacov po jej začatí a následne každých 6 mesiacov, s rešpektovaním hodnôt indexu. Akje index vyšší ako 1,5, je riziko rozvoja PML vysoké a dalšie testovanie nezmení jeho závažnost'. Ked'že včasne zachytený rádiologický dôkaz PML predchádza neurologickému deficitu vyvolaného ochorením, v manažmente liečby sa odporúčajú preventívne sériové MR skeny na detekciu včasnej rádiologickej manifestácie PML, ktorá vedie k okamžitému prerušeniu podávania NTZ. MR monitoring by mal pokračovat' 6 mesiacov po ukončení liečby NTZ (McGuigan et al., 2016)

Na zvýšenie senzitivity determinácie rizika PML/NTZ sa zvažujú aj dalšie laboratórne testy, akými je napr. zistovanie expresie L-selektínu na CD4 lymfocytoch (Schwab et al., 2016) alebo lipid-špecifických IgM pásov v mozgovomiechovom moku (Villar et al., 2015). Tieto testy si však vyžadujú dôkladné overenie spolahlivosti predtým, než by mohli byt implementované do praxe

Patofyziologické mechanizmy, ktoré vedú k rozvoju PML/NTZ u pacientov so SM, sú stále nedostatočne známe. NTZ je humanizovaná monoklonová protilátka proti a4ß1 integrínu, s čiastočným efektom aj v liečbe Crohnovej choroby.

Okrem toho, že na rozvoji PML sa u pacientov liečených NTZ zvyčajne jasne podiela poškodený neuroimunologický dozor, protilátka má aj d’alšie účinky, ktoré môžu rozvoj choroby podporit'. Jedným z nich je jej efekt na nezrelé B-LY (CD34+ LY), ktoré môžu prechovávat' vírus a zvýšit' expresiu neurotropného variantu JCV počas liečby, ako aj spôsobit’ zmeny expresie bunkových transkripčných faktorov NF-1X a Spi-B s možným zvýšením rizika vzniku PML (Berger, 2017).

\section{Lieky II. triedy}

Medzi lieky II. triedy za zarad'uje fingolimod a dimetylfumarát, obidva s nízkym, ale reálnym rizikom vzniku PML.

Bezpečnostná databáza NOVARTIS registrovala do 31. augusta 201715 prípadov PML pacientov liečených fingolimodom - z nich bolo 12 prípadov PML definitívnych a 3 pravdepodobné. K tomuto dátumu bolo liečených fingolimodom približne 217000 pacientov v klinických štúdiách i v postmarketingovom sledovaní, celková expozícia pacienta lieku prekračovala 480000 pacient-rokov. Riziko PML/fingolimod pri chýbaní predchádzajúcej liečby NTZje nízke, stanovené bolo 0,069/1 000 pacientov (95 \% konfidenčný interval: 0,039-0,114) a pomerná incidencia bola 3,12 na 100000 pacient-rokov (95 \% konfidenčný interval: 1,75-5,15).

Pravidelné sledovanie protilátok proti JC vírusu v prevencii PML má u pacientov liečených fingolimodom nejasný význam, protilátky sa štandardne nevyšetrujú. Žiadne klinické prejavy ani rádiologické znaky na MR mozgu nie sú pre PML/fingolimod jedinečné. U 14.z 15. postihnutých pacientov bol k dispozícii absolútny počet LY a ani u jedného z nich nebola $v$ čase potvrdenia PML zaznamenaná lymfopénia 4. stupňa (< ako 200 buniek/ $\mu \mathrm{L}$ ). Aj týchto málo doteraz rozpoznaných prípadov PML však nevylučuje identifikáciu špecifických návodov, vyplývajúcich z poznatkov medicíny založenej na dôkazoch, na formovanie monitoringu a stratégií na zmiernenie rizika vzniku PML u pacientov liečených fingolimodom, ako aj ostražitost' neurológov k tejto komplikácii liečby SM.

Súčasné znalosti o mechanizme účinku fingolimodu neposkytujú presvedčivý kauzálny dôkaz vzniku PML u liečených pacientov. Ukázalo sa, že fingolimod zabraňuje uvol'neniu CCR7+ve naivných T-LY a centrálnych pamätových T-LY z lymfatických uzlín, šetrí CCR7-ve efektorové pamätové T-LY. Redistribúcia CD4+ centrálnych pamätových LY z cirkulácie do lymfatických orgánov môže prispiet’ k rozvoju PML. V niektorých prípadoch, kedže pôsobením fingolimodu je sekvestrácia efektorových pamätových T-LY len parciálna, môže fingolimod potenciovat’ spolu s ostatnými faktormi redukciu imunitnej odpovede na JCV reaktiváciu (Berger et al., 2018).

$\checkmark$ liečbe psoriázy estermi kyseliny fumarátovej sa nezistilo zvýšené riziko PML. Výskyt PML u pacientov so SM liečených dimetylfumarátom (DMF) je nepredvídateliný. Do 26. júna 2019 evidovala bezpečnostná databáza spoločnosti Biogen 7 potvrdených prípadov PML u pacientov užívajúcich DMF. Väčšina prípadov (6 zo 7) sa vyskytla pri prolongovanej (> 6 mesiacov) stredne tažkej až tažkej lymfopénii, jeden prípad sa vyskytol pri miernej lymfopénii, bez dôkazu predíženého trvania lymfopénie. Do 30 apríla 2019 bolo na celom svete DMF liečených > 398000 pacientov, čo predstavuje > 740000 pacient-rokov expozície, z nich 6335 pacientov (14 065 pacient-rokov) pochádzalo z klinických štúdií (Biogen Slovakia, 2019). Pretrvávajúca lymfopénia < 500 buniek/ $\mathrm{mm}^{3}$ viac než 6 mesiacov by mala viest' k rozhodnutiu lekára o ukončení/ prerušení liečby DMF.

\section{Lieky III. triedy}

Alemtuzumab, anti-CD52 protilátka, vedie k rapídnej deplécii B aj T-LY s priemerným časom 
obnovy B-LY 7,1 mesiaca. U pacientov liečených alemtuzumabom pre SM bol zaznamenaný priemerný čas obnovy CD4 a CD8 T-LY po 20 až 35 mesiacoch. Niekto by sa mohol nazdávat', že tento imunologický scenár s návratom nezrelých B-LY a relatívna absencia cytotoxických JCV špecifických T-LY môže byt ideálnym podkladom pre rozvoj PML. Prípady PML však boli doteraz pozorované len u pacientov liečených ALZ pre chronickú lymfocytárnu leukémiu alebo menej často u transplantovaných pacientov, u ktorých je predispozícia na PML dobre známa. Žiaden prípad PML nebol zaznamenaný v klinickom rozvojovom programe, ktorý zahŕňal takmer 1500 pacientov so SM na celom svete (400 pacient-rokov $v$ následnom predíženom sledovaní) alebo u približne 9200 pacientov, ktorí boli doteraz liečení ALZ (Sanofi Genzyme, 2016). Vzhladom na známe prípady PML/ALZ pri iných diagnózach a relatívne malý počet pacientov so SM, ktorí boli doteraz alemtuzumabom liečení, potenciálne riziko PML pri tejto monoklonovej protilátke v liečbe SM nemožno vylúčit. Preto je ALZ zahrnutý do kategórie liekov III. triedy.

Riziko vzniku PML stúpa u chorých po predchádzajúcej imunosupresívnej liečbe vrátane mitoxantrónu. $V$ prípade mitoxantrónu, aj napriek možnosti vzniku lymfoidálnych malignít pri jeho užívaní, neboli hlásené žiadne prípady PML u pacientov so SM liečených týmto liekom, preto je kategorizovaný do III. triedy liekov z pohladu rizika vzniku PML v liečbe SM.

Mitoxantrón je typ II topoizomerázového inhibítora, narušuje syntézu DNA a jej obnovu. Výsledkom jeho pôsobenia je pretrvávajúca redukcia neutrofilov a lymfocytov $v$ priebehu 2 týždňov po podaní. Žiadne zmeny v pomere CD4/CD8 lymfocytov alebo v hladinách imunoglobulínov sa pri jeho užívaní nevyskytli. PML/ mitoxantrón bola pozorovaná iba u osôb s predisponujúcimi ochoreniami pre PML, akými sú non-Hodgkinov lymfóm a leukémia, ale títo pacienti dostávali aj iné imunosupresívne terapie.

Rituximab, chimerická anti-CD20 monoklonová protilátka, nebol schválený na liečbu SM, ale je široko používaný v off-label indikáciách v neurológii na liečbu chronickej zápalovej polyradikuloneuropatie, myasténie gravis, neuromyelitis optica. Napriek rozšírenému použitiu v neurologických indikáciách, sa rituximab nespája s výskytom PML, dokonca aj ked' bol podávaný v podmienkach, v ktorých existuje predisponujúce riziko PML, akými sú chronická lymfocytárna leukémia, lymfóm, reumatoidná artritída a ANCA pozitívna vaskulitída. Riziko PML je kalkulované okolo 1 na 30 000. Objavenie sa PML po podaní rituximabu je velmi variabilné a zdá sa byt náhodné, s priemernou latenciou 4 mesiace, ale boli opísané aj prípady s krátkou latenciou do 2 týždňov.

Doteraz nebol v rozsiahlom pre - a postmarketingovom sledovaní hlásený prípad PML u pacientov so SM liečených humanizovanými anti-CD20 monoklonovými protilátkami ocrelizumabom a ofatumumabom.

Do apríla 2016 nebol hlásený prípad PML/ teriflunomid u 55000 liečených pacientov, zahrnutých do klinických štúdií alebo do postmarketingového sledovania. Celková expozícia 14 mg dennej dávky predstavovala 70000 pacient-rokov. Ked’že teriflunomid je aktívny metabolit leflunomidu, lieku s vel'mi raritne pozorovanou PML, teriflunomid bol zaradený do kategórie III. triedy rizikových liekov pri SM (Berger, 2017).

\section{Herpetické vírusy}

Riziko reaktivácie latentnej herpetickej infekcie stúpa pri imunosupresívnej terapii (obzvlášt pri terapii pôsobiacej na bunkovú imunitu). Herpes simplex vírus (HSV) 1 a 2, varicella zoster vírus (VZV) a cytomegalovírus (CMV) sú najčastejšie príčiny herpetických infekcií vyžadujúcich liečbu.

Pri porovnaní skupín pacientov liečených interferónmi ßa alemtuzumabom bol u pacientov liečených ALZ zaznamenaný pozoruhodne vyšší výskyt HSV infekcií, ale aj VZV infekcií - niekedy i závažných aj napriek tomu, že protokoly klinických štúdií odporúčali podávanie acykloviru 200 mg tablety $2 \times$ denne per os počas terapie ALZ a 28 dní po jej ukončení (Cohen et al., 2012; Coles et al., 2012).

FDA (Food and Drugs Administation, USA) odporúča profylaxiu acyklovirom od začiatku terapie ALZ, až pokial' sa CD4+ LY nevrátia najmenej na 200 buniek/ $\mu \mathrm{L}$, s minimálnym trvaním profylaxie 2 mesiace, aj ked'sa CD4+ lymfocytopénia obnoví skôr. V klinických štúdiách s ALZ bola použitá nižšia dávka acykloviru, v praxi sa však z profylaktických dôvodov podáva acyclovir v dávke 400 mg tablety 2x denne a táto dávka sa považuje u liečených pacientov za správnu.

CMV choroba sa u pacientov so SM liečených ALZ vyskytuje raritne, v kontraste s jej častým výskytom u hematologických pacientov. Vzhl'adom na tento zriedkavý výskyt CMV infekcie u pacientov so SM sa u nich preventívny monitoring infekcie pomocou CMV-PCR nevyžaduje.

Fingolimod môže vd’aka svojmu efektu na transport lymfocytov teoreticky zvýšit riziko vzniku herpetických infekcií. V pilotnom klinickom programe s fingolimodom sa vyskytli u liečených pacientov dve fatálne herpetické infekcie, jedna u non-imúnneho pacienta s primárnou infekciou varicella zoster po expozícii infikovanému dietatu, druhá u pacienta s HSV encefalitídou. Ďalší fatálny prípad bol hlásený u pacienta po VZV reaktivácii. Následná analýza potvrdila celkové vyššie riziko (ale nie závažné) VZV infekcií u pacientov liečených fingolimodom v porovnaní s placebom. Všetci pacienti non-imúnni k VZV by mali byt pred imunosupresívnou liečbou očkovaní, pokial' neexistujú závažné kontraindikácie. Ked'že všeobecné riziko herpetických infekcií, obzvlášt závažných, je u pacientov liečených fingolimodom nízke, rutinná profylaxia acyklovirom sa neodporúča. Môže sa zvážit', ak je fingolimod súčasne podávaný s kortikosteroidmi alebo u pacientov s častými recidívami orálneho alebo genitálneho herpes simplex.

Na rozdiel od úvodných klinických štúdií s fingolimodom, postmarketingové údaje upozorňujú na početné prípady herpetických infekcií centrálnej nervovej sústavy (CNS) pri fingolimode, najviac vírusom HSV, ale aj na niekol'ko prípadov infekcie CNS VZV. Títo pacienti mali rôzne závažný klinický priebeh vrátane úmrtia, ale u väčšiny z nich došlo k úprave (Epstein, 2018).

Herpetickým infekciám sa nevyhnú ani pacienti liečení natalizumabom. Herpetické infekcie sa u nich vyskytujú nezávisle od trvania liečby, častejšie sa pozorujú u liečených pacientov s predchádzajúcou imunosupresívnou liečbou v anamnéze. Súčasné produktové odporúčania nenariad'ujú rutinnú profylaxiu acyklovirom. Pre pacientov liečených NTZ je riziko verzus benefit rutinnej profylaxie herpetickej infekcie nejasné, rovnako ako jej potenciálne komplikácie. Profylaxia acyklovirom sa môže zvážit u pacientov s predchádzajúcou imunosupresívnou liečbou alebo v prípade častých recidivujúcich infekci HSV (orálny alebo genitálny herpes simplex).

Pri ocrelizumabe boli opísané len mierne alebo stredne závažné herpetické infekcie, 
rutinná antivírusová profylaxia sa u liečených pacientov nevyžaduje.

Zvýšené riziko frekvencie alebo závažnosti herpetických infekcií pri d’alších liekoch aplikovaných pri SM - teriflunomid, dimetylfumarát a mitoxantrón - sa nepredpokladá. V literatúre sú len ojedinelé správy o ich výskyte (Epstein et al., 2018).

Rozsiahly diseminovaný herpes zoster v oblasti TH10-L1 s ochrnutím dolnej končatiny, ktorý sa vyvinul u pacientky s relapsujúcou remitujúcou sclerosis multiplex (RRSM) 6 mesiacov po začaté liečby DMF opísali Ma et al., 2016. Pacientka bola počas trvania choroby liečená interferónom $\beta$-1a a NTZ, potom nasledoval jeden cyklus rituximabu pre pozitívny JCV status. Pacientka nemala anamnézu vírusovej reaktivácie alebo oportúnnych infekcií a nemala žiadnu imunoterapiu viac ako rok pred začatím DMF. Nedostávala kortikoidy, absolútny počet LY bol pred začatím DMF $v$ norme. V čase VZV infekcie - 6 mesiacov po začatí DMF - poklesol absolútny počet LY o 60 \% v porovnaní so začiatkom. Exaktný mechanizmus pôsobenia DMF je neznámy. DMF môže preferenčne redukovat’ CD8+ T-LY viac ako CD4+ T-LY, ktoré sa môžu zvýšit v individuálnych prípadoch pri podozrení na vírusovú reaktiváciu. Reportovaná pacientka mala $74 \%$ pokles CD8+ T-LY verzus $57 \%$ pokles CD4+ LY. Dimetylfumarátom indukovaná lymfopénia pravdepodobne prispela k VZV reaktivácii s výsledkom diseminovaného herpes zoster. Na zvýšenom riziku vírusovej reaktivácie sa mohla podielat aj predchádzajúca liečba rituximabom.

Bezpečnostný profil DMF sa v súčasnosti vyvija. S prihliadnutím na potvrdené prípady PML/DMF a v predmetnej kazuistike k výskytu závažného diseminovaného herpes zoster pri reaktivácii VZV odporúčajú jej autori častejší laboratórny monitoring, ako aj zvýšenú pozornost' ohladom oportúnnych infekcií u pacientov s lymfopéniou. Podla autorov by sa malo pred začatím liečby DMF rovnako ako pri fingolimode zvažovat stanovenie VZV statusu a vakcinácia naivných pacientov.

V klinických skúškach s kladribínom bol pomerný výskyt infekcií, závažných infekcií, infekcií vedúcich k prerušeniu liečby alebo oportúnnych infekcií u liečených pacientov dávkou 3,5 mg/kg hmotnosti v porovnanís placebovou skupinou porovnatel'ný až na incidenciu herpetických infekcií, ktorá bola u liečených pacientov zvýšená.
Z herpetických infekcií dominoval herpes zoster s distribúciou v dermatómoch, s následným nekomplikovaným priebehom, nevyskytli sa žiadne prípady postherpetickej neuralgie. Počet nežiaducich udalostí (Adverse Events - AEs) na 100 pacient-rokov bol pre závažný herpes zoster 0,09 v skupine liečených chorých kladribínom v dávke 3,5 mg/kg a 0,05 v placebovej skupine. Väčšina herpetických infekcií sa objavila u pacientov krátko po začatí liečby kladribínom 3,5 $\mathrm{mg} / \mathrm{kg}$ váhy, v 1. a 2. roku, ale malý počet prípadov nedovoluje vytvárat’ konečné závery (Cook et al., 2019).

\section{Iné infekcie, ktorých sa možno obávat'}

Vzhladom na ich relatívnu prevalenciu a dopad na imunosupresívnu liečbu - vo väčšine klinických skúšok s liekmi na SM sa vyžadoval skríning participantov na infekcie HIV a hepatitídu C (HCV), tieto usmernenia pochopiteline pokračujú aj v klinickej praxi.

Iné oportúnne infekcie (OI), typicky spájané s infekciou HIV, boli hlásené iba výnimočne v súvislosti s liečbou SM - väčšinou išlo o lieky, ktoré ovplyvňujú transport lymfocytov (ako napr. NTZ a fingolimod), alebo o tie, ktorých výsledkom je deplécia T-LY (napr. ALZ). Kryptokokóza CNS, kože a diseminovaná kryptokokóza boli raritné pri užívaní fingolimodu a v menšej miere pri užívaní natalizumabu. Individuálne prípady Kaposiho sarkómu, kožnej histoplazmózy a CNS toxoplazmózy sa taktiež zaznamenali u HIV neinfikovaných pacientov so SM užívajúcich fingolimod. Obdobne raritné prípady výskytu pneumocystovej pneumónie, nocardiózy a listeriózy boli opísané u pacientov so SM liečených alemtuzumabom. Rutinný skríning alebo profylaxia týchto raritných ochorení nie je v tejto populácii chorých indikovaná, ale v praxi by sme na možnost' ich výskytu nemali zabúdat (Epstein et al., 2018).

Incidencia Ol bola obdobne výnimočná aj u pacientov liečených kladribínom 3,5 mg/kg hmotnosti. Výskyt neočakávaných vedlajších udalostí (Adjusted AEs) bol na 100 pacient-rokov v liečenej skupine chorých 1,08, v placebovej 1,17. Viac než polovica oportúnnych infekcií boli mukokutánne a kutánne mykotické infekcie, ktoré vyžadovali štandardnú liečbu. Oportúnne infekcie, ktoré môžu byt život ohrozujúce, akými sú PML, kryptokokóza, toxoplazmóza, pneumo- cystis jirovecii pneumonia, CMV infekcie alebo listerióza, sa v klinických skúškach s kladribínom alebo počas následnej liečby u pacientov nepozorovali (Cook et al., 2019).

Niektoré lieky používané v liečbe SM vrátane ALZ, ocrelizumabu a mitoxantrónu sa spájajú so štatisticky signifikantne zvýšeným všeobecným rizikom infekcií - väčšinou miernou alebo stredne tažkou nazofaryngitídou, infekciami horných ciest dýchacích (HCD) a močového traktu. Žiaden špeciálny preventívny postup nie je potrebný.

Napriek výskytu oportúnnych infekcií v súvislosti s užívaním fingolimodu a natalizumabu v klinických skúškach s obomi liekmi sa nepotvrdilo celkové zvýšenie všeobecného rizika infekcií. Obdobne je na tom teriflunomid, pri dimetylfumaráte sú výsledky klinických štúdii z aspektu rizika infekcií rozporné (Epstein et al., 2018). Špeciálnu pozornost’ sledovania výskytu infekcií a vedlajších účinkov liečby si bude vyžadovat' pediatrická populácia pacientov so SM liečená fingolimodom (Chitnis T et al., 2018).

Analyzované dáta z klinických štúdií s ocrelizumabom fázy II, fázy III (OPERA I, OPERA II a ORATORIO) plus štúdie VELOCE, CHORDS/ CASTING a OBOE vyhodnotili nežiaduce udalosti v súlade s MedDRA (Medical Dictionary for Regulatory Activities) k 02/2018. Do februára 2018 bolo v týchto klinických štúdiách liečených 3811 pacientov s rozdielnou dĺžkou trvania liečby. Po jej zohladnení to zodpovedá 10919 pacient-rokom. Miera infekcií bola 74,5 na 100 pacient-rokov a miera závažných infekcií bola 2 na 100 pacient-rokov. Najčastejšími závažnými infekciami boli infekcie močových ciest a pneumónia. Do septembra 2018 sa nezaznamenal žiadny prípad PML spojenej s liečbou ocrelizumabom (Lisý, 2019).

\section{Infekcie počas obdobia} lymfopénie stupňa 3 a 4/kladribín

Post-hoc analýza špeciálne skúmala infekčné nežiaduce udalosti a závažné nežiaduce udalosti (AEs a SAEs), ktoré sa vyskytli počas období lymfopénie stupňa 3 alebo 4 u pacientov liečených kladribínom 3,5 mg/kg hmotnosti. Lymfopénia stupňa 3 alebo 4 bola na začiatku definovaná (ALC - Absolute Lymphpocyte Count) <0,5 × 109 buniek/L až do obnovy ALC > 0,5 × 109 buniek/L, plus 2 týždne.

Počas obdobia lymfopénie 3. a 4. stupňa sa infekcie vyskytovali so zvýšenou frekvenciou. 
Typ infekčnej príhody hlásený počas obdobia lymfopénie 3. a 4. stupňa sa nelíšil od tých, ktoré sa vyskytli mimo tohto obdobia. Herpes zoster sa v tomto období vyskytoval častejšie (AEs na 100 pacient-rokov 4,50 verzus 0,73 bez lymfopénie 3. a 4. stupňa). Klinický profil herpetickej infekcie nebol komplikovaný. Rovnako bol pri týchto stupňoch lymfopénie frekventovanejší výskyt infekcií horného respiračného traktu.

Incidencia oportúnnych infekcií počas závažnej lymfopénie bola celkovo nízka, porovnatel'ná u liečených pacientov kladribínom $3,5 \mathrm{mg} / \mathrm{kg}$ hmotnosti verzus placebová skupina. Žiaden zo známych prípadov OI nebol závažný (Cook et al., 2019).

\section{Očkovanie}

Cielom aktívnej imunizácie je navodenie obranyschopnosti organizmu pred možnou expozíciou infekčným agensom. Očkovacie látky môžu predstavovat' usmrtené mikroorganizmy, živé oslabené (atenuované) mikroorganizmy, toxoidy (anatoxíny), purifikované antigény pripravené z tiel mikroorganizmov (podjednotkové) a najnovšie rekombinantné vakcíny a DNA - vakcíny (Buc, 2016).

Očkovanie proti varicelle sa špeciálne odporúča ako preventívny postup zdravotnej starostlivosti pred začatím užívania fingolimodu a kladribínu u indikovaných pacientov, ale všetci pacienti liečení pre SM môžu byṫ očkovaní vrátane sezónneho očkovania proti chrípke. Pred každým očkovaním pacienta so SM sa však vyžaduje zvážit jeho nevyhnutnost' a všetky rizikové faktory, ktoré by mohli podmienit negatívny dopad očkovania na pacienta. Pokial'sa neobjavia podporné dáta o bezpečnosti živých atenu-

ovaných vakcín, mali by sme sa im u pacientov so SM užívajúcich imunosupresívnu terapiu vyhýbat'. Minimálne 4 týždne sa typicky odporúčajú medzi podaním živej atenuovanej vakcíny a začatím imunosupresie (niektoré produktové odporúčania pri SM liekoch navrhujú 6 týždňov). Živé atenuované vakcíny sú kontraindikované

\section{LITERATÚRA}

1. Berger JR. Classifying PML risk with disease modifying therapies. Multiple sclerosis and Related Disorders, 2017; 12: 59-63.

2. Berger JR, Cree BA, Greenberg B, Hemmer B, Ward BJ, Dong VM, Merschhemke M. Progressive multifocal leukoencephalopathy after fingolimod treatment. Neurology 2018; 90: 1-7. doi: 10.1212/WNL.00000000000005529.

3. Biogen Slovakia: Tysabri - globálne údaje o PML. Aktualizácia od uvedenia na trh, marec 2018 počas terapie a variabilné je obdobie očkovania po jej ukončení - minimálne v rozsahu 2-6 mesiacov, v závislosti od farmakokinetických vlastností lieku.

Inaktivované (mŕtve) vakcíny, podjednotkové alebo toxoidové sú bezpečnejšie ako živé atenuované vakcíny, ale imunologické odpovede môžu byt' utlmené alebo chýbat’ v kontexte imunosupresie (hoci novel adjuvans obsahujúci AS01B v rekombinantnej zoster vakcíne môže teoreticky exacerbovat’ SM). Táto situácia vyžaduje d’alší imunologický výskum, ale aj postmarketingové sledovanie, ked'že nie je možné zastavit’ používanie vakcín.

$\checkmark$ randomizovanej otvorenej štúdii s ocrelizumabom boli pacienti s RSM schopní dosiahnut' humorálne (protilátkové) odpovede, i ked’ znížené, na očkovaciu látku obsahujúcu tetanový toxoid, na 23-valentnú pneumokokovú polysacharidovú očkovaciu látku s následným preočkovaním alebo bez neho, na očkovaciu látku obsahujúcu neoantigén KLH (Keyhole Limpet Hemocyanin - hemocyanín kuželnatky) a na očkovaciu látku proti sezónnej chrípke. Pacientov liečených ocrelizumabom sa odporúča zaočkovat' inaktivovanými očkovacími látkami proti sezónnej chrípke.

Mitoxantrón môže rovnako ako ostatné chemoterapeutiká narušit imunologické odpovede po očkovaní do 3 mesiacov. Dostupné dáta podporujú imunogenicitu vakcín (hoci niekedy redukovanú v porovnaní s pacientmi liečenými placebom) podávaných pacientom liečeným natalizumabom, fingolimodom, dimetylfumarátom, teriflunomidom - takže inaktivované, podjednotkové a toxoidové vakcíny sa môžu podávat' pacientom so SM bez ohladu na typ ich liečby (Epstein, 2018).

\section{Záver}

Súčasnost' prináša široké možnosti liečby SM. Okrem dobre známych injekčne podávaných interferónov ß a glatiramer acetátu, s ktorými sú

dlhoročné skúsenosti a majú vynikajúci bezpečnostný profil, ale žial' aj limitovanú účinnost' - je tu celý rad imunomodulačných a imunosupresívnych terapií s komfortnejším podávaním, ktoré indikujeme predovšetkým v prípade potrebnej eskalácie liečby alebo pri vysokoaktívnej SM ako lieky prvej vol'by.

Celkovo sú tieto lieky bezpečné, majú taktiež vynikajúci risk verzus benefit profil a môžu dramaticky zlepšit kvalitu života pacientov s potenciálne invalidizujúcou neurologickou chorobou. Zároveň však musíme predvídat' a riešit všetky možné nežiaduce udalosti v súvislosti s užívaným liekom, minimalizovat’ ich negatívny dopad na pacienta a zabezpečit, aby nadalej z liečby profitoval.

Poznatky o prisudzovaných infekčných rizikách jednotlivých liekov máme z klinických štúdií z heterogénnej populácie pacientov so SM. Aj ked' ich samozrejme rešpektujeme, môžu viest' k nadhodnoteniu významu týchto rizík v danej populácii chorých, najmä u tých, ktorí nemajú zásadný imunologický deficit alebo v anamnéze expozíciu over-lap imunosupresívnej terapie. Mohli by sme ich nechtiac z vhodnej liečby vylúčit. Niektoré imunosupresíva majú predvídatelné alebo dobre definované riziká možných infekčných komplikácií, pri iných sú riziká nejasné.

V stratifikácii rizika PML sa urobil v posledných rokoch značný pokrok. So zlepšením našich poznatkov o patogenéze PML, akými je prínos genetických faktorov hostitela a potenciálne terapie na elimináciu JCV s využitím CRISP-Cas9 (Cluster Regularly Interspased Short Palindromic Repeats-associated protein 9), existuje možnost', že nebezpečenstvo PML môže byt’ pri rizikových liekov eliminované (Berger, 2017).

$\checkmark$ praxi vítame metodológiu skríningových vyšetrení aj odporúčaný manažment sledovania vrátane laboratórnych vyšetrení pri jednotlivých liekoch. Je to určite spôsob preventívnych opatrení proti nežiaducim udalostiam vrátane infekčných.

4. Biogen Slovakia: PML/dimetylfumarát. 2019 5. Brew BJ, Davies NW, Cinque P, et al. Progressive multifocal leukoencephalopathy and other forms of JC virus disease. Nat Rev Neurol. 2010; 6: 667-79.

6. Buc M. Autoimunita a autoimunitné choroby. 2. prepravované vydanie. Bratislava: VEDA 2016: s. 143. s. 401-408. 7. Centers for Disease Control and Prevention. Division of Tuberculosis Elimination. Latent Tuberculosis infection: A Guide for Primary Health Care Providers. Treatment of latent
TB infection. Centers for Disease Control and Prevention. 2016. Dostupné na: http://www.cdc.gov/tb/publications/ Itbi/treatment.htm.

8. Cohen JA, Coles AJ, Arnold DL, et al. CARE-MSI investigators. Alemtuzumab versus interferon beta $1 \mathrm{a}$ as first-line treatmen for patients with relapsing remitting multiple sclerosis: a randomised controlled phase 3 trial. Lancet 2012; 380: 1819-28. 9. Coles AJ, Twyman CL, Arnold DL, et al. CARE-MS II investigators. Alemtuzumab for patients with relapsing multiple sc- 
lerosis after disease-modifying therapy, a randomised controlled phase 3 trial. Lancet 2012; 380: 1829-39.

10. Comi G, Freedman MS, Kappos L, Olsson TP, Miller AE, Wolinsky JS, O'Connor PW, Benamor M, Dukovic D, Truffinet P, Leist TP. Pooled safety and tolerability data from four placebo-controlled teriflunomide studies and extensions. Multiple Sclerosis and Related Disorders 2016, 5: 97-104

11. Cook S, Leist T, Comi C, et al. Safety of cladribine tablets in the treatment of patient with multiple sclerosis: An integrated analysis. Multiple sclerosis and related disorders 2019; 29: 157-167. 12. Epstein DJ, Dunn J, Deresinski S. Infectious Complications of Multiple Sclerosis Therapies: Implications for Screening, Prophylaxis, and Management. Open Forum Infectious Diseases (OFID) 2018; p. 1-8. doi: 10.1093/ofid/ofy174.

13. Ho PR, Koendgen H, Cambell N, et al. Risk of natalizumab-associated progressive multifocal leukoencephalopathy in patients with multiple sclerosis: a retrospective analysis of data from four clinical studies. Lancet Neurol. 2017; 16: 925-33. 14. Chitnis T, et al. (17co-authors) for PARADIGMS Group. Trial of Fingolimod versus Interferon Beta-1a in Pediatric Multiple Sclerosis. N Engl J Med. 2018; 379: 1017-27. doi: 10.1056/ NEJMoa1800149.
15. Lisý L’. 5-ročné výsledky liečby okrelizumabom u pacientov s relapsujúcou sclerosis multiplex. Neurológia pre prax 2019; 20: suppl. 3.

16. Ma BB, Ostrow LW, Newsome SD. Disseminated zoster with paresis in a multiple sclerosis patient treated with dimethyl fumarate. Neurol Neuroimmunol Neuroinfamm. 2016; 3: e203. 17. McGuigan C, Craner M, Guadagno J, et al. Stratification and monitoring of natalizumab-associated progressive multifocal leucoencephalopathy risk: recommendation from an expert group. J Neurol Neurosurg Psychiatry. 2016; 87: 117-25. 18. Reddy KR, Beavers KL, Hammond SP, Lim JK, Falck-Ytter YT: American Gastroenterological Association Institute. American Gastroenterological Association Institue guideline on the prevention and treatment of hepatitis B virus reactivation during immunosuppressive drug therapy. Gastroenterology 2015; 148: 215-9., quiz e16-7.

19. Sanofi Genzyme 2019. Internal data on file. 20. Sanofi Genzyme 2016. Internal data on file. 21. Súhrn charakteristických vlastnostílieku Ocrevus. Roche Slovensko, s. r. o. 2018. Dostupné na www.ema.europa.eu. 22. Schwab N, Schneider-Hohendorf T, Melzer N, et al. Natalizumab-associated PML: challenges with inciden- ce, resulting risk, and risk stratification. Neurology 2017; 88: 1197-205.

23. Schwab N, Schneider-Hohendorf T, Pignolet B, Spandaro M, Gorlich D, Meinl I, Windhagen S, Tackenberg B, Breuer J, Canto J, Kumpfel E, Hohlfeld R, Siffrin V, Luessi F, Posevitz- Fejfar A, Montalban X, Meuth SG, Zipp F, Golg R, Du Pasquier RA, Kleinschnitz C, Jacobi A, Comabella M, Bertolotto A, Brassat D, Wiendl H. PML risk stratification using anti-JCV antibody index and L-selectin. Mult Scler. 2016; 22(8): 1048-1060. 24. SPC lieku Aubagio [online]. Dostupné na www.sukl.sk. 25. SPC lieku Mavenclad [online]. Dostupné na www.sukl.sk. 26. SPC lieku Ocrevus [online]. Dostupné na www.sukl.sk. 27. Vermersch P, Czlonkowska A, ME Grimaldi L, † Convfavreux CH, Comi G, Kappos L, Olson TP, Benamor M, Bauer D, Truffinet $\mathrm{P}$, Churg M, Miller AE, Wolinsky JS, Freedman MS and O'Connor P for the TENERE Trial Group. Mult Scler Journal. 2014; 20: 705-716. DOI: 10.1177/1352458513507821.

28. Villar ML, et al. (45 spoluautorov). Lipid-specific immunoglobulin M bands in cerebrospinal fluid are associated with a reduced risk of developing progressive multifocal leukoencephalopathy during treatment with natalizumab. Ann Neurol. 2015; 77(3): 447-457.

\section{Závažné infekcie komplikujúce liečbu sclerosis multiplex}

doc. MUDr. Eleonóra Klímová, CSc.

\section{Vychází jako supplementum C časopisu Neurologie pro praxi} Neurol. praxi 2020; 21(Suppl C)

\section{Vydavatelství a nakladatelství:}

Solen, s. r. O., Lazecká 297/51, 77900 Olomouc, IČ 25553933

Redakce: Mgr. Zdena Bartáková, bartakova@solen.cz

Obchodní oddělení: Ing. Lenka Mihulková, mihulkova@solen.cz

Grafická úprava a sazba: Lucie Šilberská, silberska@solen.cz

Distribuce: SOLEN, s.r. O., 2019

Tisk: Trifox, s. r. O., Šumperk

Počet stran: 12

ISBN 978-80-7471-301-9

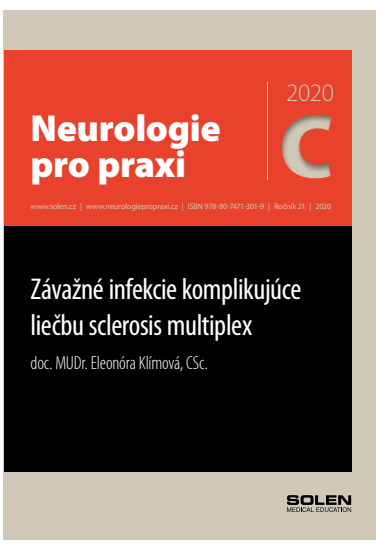

Vydavatel nenese odpovědnost za údaje a názory autorů textů či inzerátů.

Reprodukce obsahu je povolena jen s prímým souhlasem redakce.

Nejnovější informace o našich publikacích naleznete v e-shopu na www.solen.cz 


\section{ELEKTRONICKÁ UNIVERZITA}

Akreditované e-learningové kurzy

Študujte ZADARMO a získávajte kredity ČLK

WWW.EUNI.CZ

\section{Zaostrené na...}

Hlavná strana > Študovňa > Ochorenia centrálej nervovej sústavy

- Nadužívanie súčasnej medikácie v liečbe migrény

Autor: MUDr. Tomáš Nežádal, Ph.D.

- Migréna a jej liečba

Autor: MUDr. Jolana Marková, FEAN

- Infekčné ochorenia a vakcinácia u pacientov s roztrúsenou sklerózou

Autor: MUDr. Hana Roháčová, Ph.D., prof. MUDr. Vojtěch Thon, Ph.D.

- Roztrúsená skleróza a tehotenstvo

Autor: MUDr. Pavla Hanulíková, MUDr. Pavel Hradílek, Ph.D., MUDr. Eva Meluzínová

- Gynekologicko-pôrodnícka problematika u pacientok

so SM a trendy v IVF a hormonálnej antikoncepcii

Autor: doc. MUDr. Tonko Mardešić, CSc.

\section{Vzdelanie, ktoré riadite vy!}

- odborne garantované informácie z medicínskych odborov už od roku 2006

- videoprednášky, prezentácie na stiahnutie, kedykol'vek z pohodlia domova

- online pre všetky zdravotnícke profesie

- vedomostné kvízy a kalendár akcií

- zadarmo, stačí sa zaregistrovat́

\section{Partnerom EUNI.cz je ČLS JEP}

Pridajte sa k viac než 20000 zdravotníkom, ktorí už študujú na www.EUNI.cz 
